http://ojs.umrah.ac.id/index.php/gantang/index

\title{
Pengembangan Perangkat Pembelajaran Berorientasi Berpikir Tingkat Tinggi Model Problem Based Learning Materi Peluang Kelas VIII SMP
}

\author{
Prilia Devina $^{1^{*}}$, Elfis Suanto ${ }^{2}$, Kartini $^{3}$ \\ 1,2,3 Universitas Riau, Kota Pekanbaru, Riau 28761, Indonesia \\ Pengiriman: 15/Januari/2021; Diterima25/Maret/2021; Publikasi: 31/Maret/2021 \\ DOI: https://doi.org/10.31629/jg.v6i1.2867
}

\begin{abstract}
Abstrak
Fokus utama tujuan pembelajaran matematika dan tuntutan kurikulum saat ini adalah mengembangkan keterampilan berpikir tingkat tinggi siswa. Sedangkan keterampilan berpikir tingkat tinggi siswa SMP terkategori cukup dan masih harus ditingkatkan. Penelitian ini bertujuan untuk menghasilkan perangkat pembelajaran matematika berorientasi berpikir tingkat tinggi berdasarkan model problem based learning yang valid pada materi Peluang kelas VIII SMP. Perangkat pembelajaran terdiri dari Silabus, Rencana Pelaksanaan Pembelajaran (RPP) dan Lembar Kerja Siswa (LKS). Penelitian ini merupakan penelitian pengembangan dengan model ADDIE. Proses pengembangan yang dilakukan pada penelitian ini hanya sampai tahap implementasi. Berdasarkan hasil analisis data diperoleh data tingkat validitas aspek Silabus, RPP, dan LKS lebih dari 60\%. Hasil penelitian disimpulkan bahwa perangkat pembelajaran matematika berorientasi berpikir tingkat tinggi berdasarkan model Problem Based Learning pada materi peluang kelas VIII SMP/MTs yang dikembangkan dinyatakan valid dan dapat digunakan dalam proses pembelajaran di dalam kelas.
\end{abstract}

Kata kunci: berpikir tingkat tinggi; materi peluang

\begin{abstract}
The mathematics learning objectives and the demands of the current curriculum is to developing student's higher order thinking. In fact the higher order thinking skills of junior high school students are categorized sufficient. This research aim to produces valid mathematics learning devices oriented by higher order thinking skills based on problem based learning on mathematics opportunity material for 8 grade junior high school. The learning devices consist of Syllabus, Lesson Plans and Student Worksheet. This research is using the ADDIE. The development process achieved in this research only until the implementation stage. Based on the results of data analysis, the validity level of Syllabus, Lesson Plans and Student Worksheet was more than $60 \%$. The result of the study concluded that the mathematics learning devices oriented by higher order thinking skills based on problem based learning on probability material for 8 grade junior high school was declared valid and can be used in the learning process in the classroom.
\end{abstract}

Keywords: higher order thinking; probability material 


\section{JURNAL GANTANG. Maret 2021; VI(1): 61 - 73 \\ p-ISSN. 2503-0671 \\ e-ISSN. 2548-5547}

\section{Pendahuluan}

Penelitian Susanto \& Retnawati (2016) menyatakan rancangan pembelajaran semestinya dipersiapkan dengan mempertimbangkan kebutuhan siswa dan tuntutan kurikulum yang telah dirancang oleh pemerintah. Tujuan pembelajaran matematika berdasarkan kurikulum 2013 yang berlaku difokuskan pada pengembangan keterampilan berpikir tingkat tinggi siswa. Namun melalui penelitian yang dilakukan oleh Kurniawati, dkk (2016), diperoleh hasil bahwa dari keseluruhan subjek penelitian didapatkan siswa hanya memiliki keterampilan berpikir tingkat tinggi dengan kategori sedang dan rendah. Penilaian yang dilakukan yaitu mengukur keterampilan menganalisis, mengevaluasi, mengkreasi, logika, dan penalaran siswa dalam menjawab soal-soal yang diberikan.

Penelitian serupa yang dilakukan oleh Prasetyani, dkk (2016), memperoleh hasil bahwa keterampilan berpikir tingkat tinggi siswa pada pelajaran matematika dengan model problem based learning terkategori cukup. Hasil penelitian ini merupakan fakta bahwa keterampilan berpikir tingkat tinggi siswa masih harus ditingkatkan untuk mencapai tujuan pembelajaran matematika berdasarkan tuntutan kurikulum yang telah ditetapkan.

Menurut Suryapuspitarini dalam (Suhady et al., 2020), target penerapan HOTS untuk mencapai tujuan kurikulum 2013 yaitu siswa mampu mengikuti proses pembelajaran secara aktif melalui diskusi dan pemecahan masalah baik secara mandiri, kelompok kecil, maupun klasikal. Selanjutnya Ariyana, dkk (2018) menambahkan, keterampilan berpikir tingkat tinggi siswa erat kaitannya dengan keterampilan berpikir sesuai dengan ranah kognitif yang dilakukan dalam proses belajar dan mengajar. Ranah kognitif yang dilakukan dalam proses pembelajaran meliputi kemampuan siswa dalam menyatakan kembali konsep/ prinsip yang telah dipelajari dalam proses pembelajaran yang telah didapatnya. Tujuan pembelajaran pada ranah kognitif menurut Bloom merupakan segala aktivitas pembelajaran dengan 6 tingkatan sesuai dengan jenjang terendah sampai tertinggi yaitu mengingat (C1), memahami (C2), menerapkan/mengaplikasikan (C3), menganalisis (C4), menilai/mengevaluasi (C5), dan mengkreasi/mencipta (C6). Anderson dan Krathwoll melalui taksonomi yang direvisi memiliki rangkaian proses yang menunjukkan kompleksitas kognitif yaitu dengan menambahkan dimensi pengetahuan, seperti: pengetahuan faktual, pengetahuan konseptual, pengetahuan prosedural, dan pengetahuan metakognitif (Ariyana et al., 2018).

Sehubungan dengan tuntutan rancangan pembelajaran yang berorientasi berpikir tingkat tinggi siswa, Riadi (2016) melalui penelitiannya, mendapatkan fakta bahwa saat ini guru masih menggunakan perangkat pembelajaran yang belum secara khusus membimbing siswa dalam peningkatan keterampilan berpikir tingkat tinggi siswa. Mengembangkan sebuah perangkat pembelajaran yang berorientasi pada keterampilan berpikir tingkat tinggi harus memperhatikan model pembelajaran yang dirasa tepat untuk digunakan dan sesuai dengan karakteristik materi pelajaran yang akan dipelajari. Hasil penelitian Fatchiyah (2016), menunjukkan bahwa penerapan model PBL dalam pembelajaran terbukti lebih unggul meningkatkan keterampilan berpikir tingkat tinggi dari pada pembelajaran menggunakan metode ceramah bervariasi. Serupa dengan hal tersebut Herman (2007), menyimpulkan pembelajaran model problem based learning secara signifikan lebih baik daripada pembelajaran konvensional dalam meningkatkan keterampilan berpikir matematis tingkat tinggi siswa SMP. Selanjutnya penelitian mengenai perangkat pembelajaran oleh Jailani \& Retnawati (2016), memperoleh kesimpulan bahwa pemanfaatan perangkat pembelajaran model problem based learning efektif untuk meningkatkan keterampilan berpikir tingkat tinggi siswa.

Menurut Ward \& Stepien dalam (Ngalimun, 2014), problem based learning adalah suatu model pembelajaran yang melibatkan siswa untuk memecahkan suatu permasalahan melalui 
tahapan metode ilmiah sehingga siswa dapat memperoleh pengetahuan yang berhubungan dengan permasalahan yang diberikan. Model problem based learning menjadikan masalah sebagai fokus pembelajaran yang akan diselesaikan melalui diskusi kelompok sehingga dapat memberi pengalaman-pengalaman belajar secara langsung kepada siswa. Menurut Tan dalam (Rusman, 2014), melalui penerapan model problem based learning keterampilan berpikir siswa dapat dioptimalisasikan melalui proses kerja yang sistematis, sehingga siswa dapat mengasah, menguji, dan mengembangkan keterampilan berpikir secara berkesinambungan. Berdasarkan beberapa pendapat para ahli tersebut dapat disimpulkan bahwa model problem based learning adalah suatu proses pembelajaran yang diawali dengan menyajikan suatu permasalahan kehidupan nyata yang akan dipecahkan siswa melalui proses yang sistematis untuk mengkonstruksi pengetahuannya.

Permasalahan dalam bidang matematika biasanya berbentuk soal, namun tidak semua soal dapat dikatakan sebagai masalah atau permasalahan. Seperti pendapat Hudojo dalam (Haryani, 2011), suatu soal dikatakan masalah tergantung pada pengetahuan yang dimiliki penjawab soal, karena dapat terjadi bagi seseorang soal itu dapat dijawab dengan menggunakan prosedur rutin baginya, namun bagi orang lain soal tersebut memerlukan pengorganisasian pengetahuan yang telah dimiliki secara tidak rutin dan orang tersebut tertantang untuk menjawab/memecahkannya. Pendapat ini diperjelas NCTM dalam (Haryani, 2011), dikatakan bahwa masalah adalah suatu soal matematika yang tidak ada cara yang dapat langsung digunakan untuk menyelesaikannya. Berdasarkan pendapat tersebut tampak bahwa pemilihan tipe masalah sangat penting dilakukan sebelum disuguhkan kepada siswa. Hasil penelitian oleh Hasyim \& Andreina (2019) menyimpulkan bahwa melalui penyelesaian soal open ended HOTS siswa dengan kemampuan tinggi mampu memenuhi indikator menganalisis, mengevaluasi, hingga mencipta; sedangkan
HOTS siswa dengan kemampuan sedang mampu memenuhi indikator menganalisis dan mengevaluasi; serta HOTS siswa dengan kemampuan rendah hanya mampu memenuhi indikator menganalisis dan belum dapat dikatakan memenuhi indikator mengevaluasi dan mencipta. Berdasarkan penelitian tersebut terlihat bahwa penyelesaian soal open onded dapat memfasilitasi dalam peningkatan HOTS siswa.

Menurut Arends dalam (Trianto, 2014) model problem based learning merupakan model pembelajaran yang mengorientasi siswa kepada masalah autentik. Permasalahan dalam bidang matematika biasanya berbentuk soal, namun tidak semua soal dapat dikatakan sebagai masalah atau permasalahan. Soal-soal bertipe pemecahan masalah identik dengan soal cerita dengan menggambarkan permasalahan yang akan dipecahkan. Fitriana \& Mampouw (2019), menyatakan bahwa peluang termasuk materi matematika yang berhubungan langsung dengan kehidupan nyata sehingga masalah-masalah peluang dapat dinyatakan dengan soal cerita. Grahastuti (2020) selanjutnya menjelaskan kesulitan belajar yang dialami siswa pada materi peluang adalah kurangnya pemahaman bahasa matematika dan kesulitan dalam mentransfer pengetahuan. Indikator kesulitan belajar siswa pada materi peluang membutuhkan tingkatan berpikir tingkat tinggi untuk mengatasi masalah: kurangnya pemahaman mengenai hubungan antara dua konsep, perbedaan antara dua konsep, alasan dari suatu argumentasi, dan pemilihan rumus dalam menyelesaikan permasalahan yang diberikan. Peneliti merasa konten peluang dapat mendukung tujuan penelitian untuk mengembangkan pembelajaran berorientasi pada keterampilan berpikir tingkat tinggi berdasarkan level kognitif Bloom berdasarkan model problem based learning.

Berdasarkan tuntutan pemerintah berupa program pengembangan pembelajaran berorientasi pada keterampilan berpikir tingkat tinggi, kondisi proses belajar mengajar di lapangan, efektifitas model pembelajaran problem based learning, serta konten peluang 


\section{JURNAL GANTANG. Maret 2021; VI(1): 61 - 73 \\ p-ISSN. 2503-0671 \\ e-ISSN. 2548-5547}

yang dapat mendukung pembelajaran berorientasi pada keterampilan berpikir tingkat tinggi maka tujuan dilaksanakannya penelitian ini adalah untuk menghasilkan produk berupa perangkat pembelajaran matematika berorientasi berpikir tingkat tinggi berdasarkan model problem based learning pada materi peluang yang memenuhi standar kesahan (validitas) yang ditentukan.

\section{Metode Penelitian}

Penelitian yang dilakukan merupakan penelitian pengembangan. Menurut Sugiyono (2008), penelitian dan pengembangan didefenisikan sebagai suatu metode penelitian yang digunakan untuk menghasilkan produk tertentu dan menguji keefektifan produk tersebut. Penelitian yang dilakukan tidak menguji keefektifan produk yang dikembangkan. Hal ini didasari oleh pendapat Rayanto \& Sugianti (2020) menyatakan bahwa penelitian pengembangan dapat dilakukan dalam bentuk yang paling sederhana, yaitu kajian tentang pengembangan pembelajaran yang melibatkan komponen proses tertentu saja. Penelitian yang dilakukan bermaksud untuk menghasilkan produk baru berupa perangkat pembelajaran matematika berorientasi berpikir tingkat tinggi yang terdiri dari silabus, RPP, dan LKS pada materi peluang dengan menggunakan model problem based learning yang diuji tingkat kesahannya namun tidak diuji tingkat keefektifannya. Perangkat pembelajaran yang dihasilkan digunakan dalam pembelajaran peluang tingkat SMP, sehingga yang menjadi subjek dalam penelitian ini adalah siswa-siswi kelas VIII tingkat SMP/Mts. Penelitian dipandu dengan kerangka kerja model pengembangan ADDIE. Model pengembangan ADDIE terdiri dari lima tahap, yaitu tahap analysis, tahap design, tahap development, tahap implementation, dan tahap evaluation (Rusdi, 2018). Langkah-langkah pengembangan yang dilakukan dalam penelitian ini diringkas menjadi alur kerja yang dapat dilihat seperti Gambar 1.

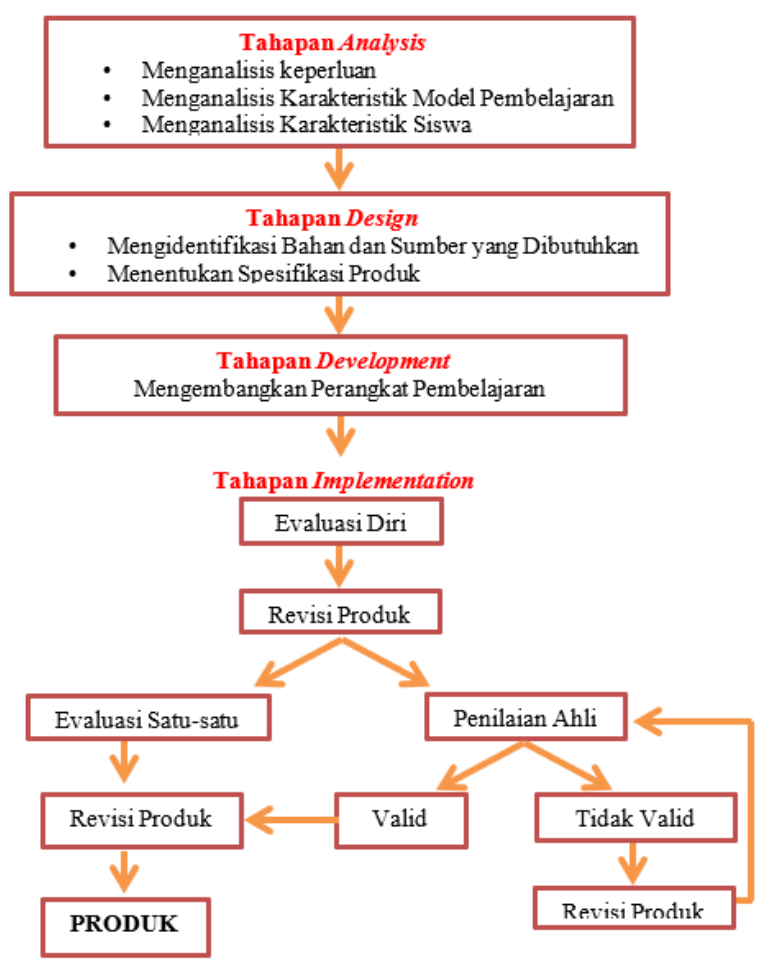

Gambar 1. Langkah-langkah pengembangan

Data yang digunakan dalam penelitian ini merupakan data kualitatif berupa deskripsi masukan, respon, kritik, dan saran dari validator terhadap silabus, RPP, dan LKS yang dijadikan sebagai bahan pertimbangan untuk memperbaiki produk yang dihasilkan. selain itu penggunaan data kuantitatif pada penelitian ini bertujuan untuk mengetahui kualitas produk yang akan dikembangkan. Kualitas produk akan terlihat dari nilai yang telah diolah berdasarkan lembar validasi oleh validator untuk mengetahui tingkat kesahan produk.

Penelitian yang dilakukan membutuhkan alat ukur yang dapat digunakan untuk mengukur ketercapaian tujuan penelitian. Instrumen pengumpul data yang digunakan pada penelitian ini lembar validasi perangkat pembelajaran. Lembar validasi perangkat pembelajaran dirancang untuk mempermudah validator dalam melakukan penilaian dan memberikan saran terhadap produk yang dikembangkan. Lembar validasi silabus, RPP dan LKS yang digunakan berupa formulir yang berisi pernyataanpernyataan menggunakan skala Likert dengan 5 skala yaitu 1, 2, 3, 4 dan 5 yang menyatakan 
sangat tidak sesuai, tidak sesuai, kurang sesuai, sesuai dan sangat sesuai (Arifin, 2010).

Kriteria kesahan perangkat pembelajaran yang dikembangkan diadaptasi dari Sidek \& Jamaludin (2008), melalui perhitungan:

Tingkat Validitas $=\frac{\text { Jumlah Skor }(\mathrm{x})}{\text { Skor Maksimum }} \times 100 \%$

Sumber: Modifikasi Sidek \& Jamaludin, 2008

Apabila persentase data hasil uji kesahan perangkat pembelajaran menunjukkan lebih atau sama dengan $60 \%$ maka perangkat pembelajaran dinyatakan sah. Apabila persentase yang diperoleh dari hasil analisis data hasil uji kesahan perangkat pembelajaran menunjukkan kurang dari $60 \%$ maka perangkat pembelajaran dinyatakan tidak sah dan akan dilakukan perbaikan berdasarkan komentar dan saran dari validator.

\section{Hasil dan Pembahasan}

Penelitian pengembangan yang telah dilaksanakan menghasilkan perangkat pembelajaran matematika berorientasi berpikir tingkat tinggi berdasarkan model Problem Based Learning pada materi peluang yang terdiri dari silabus, RPP, dan LKS yang sah (valid). Pengembangan perangkat pembelajaran dilakukan melalui kerangka kerja ADDIE. Akibat pandemi COVID-19 yang sedang terjadi, segala aktivitas dilakukan di rumah dan sekolah terpaksa diliburkan sehingga tidak memungkinkan untuk mengimplementasikan perangkat pembelajaran yang telah dihasilkan. Oleh karena itu penelitian dilakukan hingga tahap penilaian ahli.

Pada tahap analysis, peneliti menemukan masalah pendidikan khususnya dalam pelajaran matematika yang membutuhkan solusi untuk permasalahan yang dihadapi. Masalah yang dihadapi adalah lemahnya tingkat keterampilan berpikir tingkat tinggi siswa, terkhusus siswa SMP. Perbaikan kurikulum 2013, mengharapkan proses pembelajaran dapat membantu siswa untuk meningkatkan keterampilan berpikir tingkat tinggi, karena berpikir tingkat tinggi dapat mendorong siswa untuk berpikir secara luas dan mendalam tentang materi pelajaran. Peneliti menganalisis perangkat pembelajaran yang diharapkan dapat membantu meningkatkan keterampilan berpikir tingkat tinggi siswa melalui kegiatan belajar mengajar di dalam kelas. Upaya mengembangkan perangkat pembelajaran yang berorientasi pada keterampilan berpikir tingkat tinggi siswa, peneliti menganalisis karakteristik berbagai model pembelajaran sehingga memutuskan akan menggunakan model Problem Based Learning dalam kegiatan belajar mengajar. Terakhir, peneliti menganalisis kebutuhan siswa tentang permasalahan yang dihadapi dalam pembelajaran matematika.

Beberapa penelitian tentang perangkat pembelajaran matematika yang berorientasi pada keterampilan berpikir tingkat tinggi seperti keefektifan pemanfaatan perangkat pembelajaran berbasis masalah untuk meningkatkan HOTS dan karakter siswa oleh Jailani \& Retnawati (2016) diperoleh kesimpulan bahwa pemanfaatan perangkat pembelajaran berbasis masalah efektif untuk meningkatkan HOTS dan pembelajaran berbasis masalah lebih baik dibandingkan dengan pembelajaran langsung untuk meningkatkan HOTS. Selain itu, penelitian mengenai pengembangan perangkat pembelajaran problem posing berorientasi penerapan HOTS pada materi kesebangunan kelas IX oleh Kasturi, dkk (2015), diperoleh hasil penelitian bahwa hasil belajar siswa yang mengikuti pembelajaran problem posing berorientasi penerapan HOTS lebih baik daripada hasil belajar siswa yang mengikuti pembelajaran matematika konvensional. Penelitian serupa olehSetiawan \& Junaedi (2012) tentang pengembangan perangkat pembelajaran matematika dengan pendekatan problem based learning untuk meningkatkan keterampilan higher order thinking memperoleh hasil uji coba di lapangan yang menunjukkan bahwa implementasi perangkat pembelajaran dengan pendekatan problem based learning materi bangun ruang sisi datar berhasil menuntaskan nilai keterampilan higher order thinking siswa baik secara individual maupun secara klasikal, serta terdapat pengaruh positif aktivitas siswa terhadap keterampilan higher order thinking siswa, yang berarti bahwa 


\section{JURNAL GANTANG. Maret 2021; VI(1): 61 - 73 \\ p-ISSN. 2503-0671 \\ e-ISSN. 2548-5547}

keaktifan siswa dalam pembelajaran dengan pendekatan problem based learning dapat meningkatkan keterampilan higher order thinking siswa. Berdasarkan beberapa penelitian terdahulu, peneliti akan mengembangkan perangkat pembelajaran berorientasi berpikir tingkat tinggi berdasarkan level kognitif Bloom pada materi lainnya yaitu materi peluang kelas VIII SMP/MTs.

Pada tahap design, peneliti menyiapkan berbagai sumber yang dibutuhkan untuk proses pengembangan perangkat pembelajaran matematika berorientasi berpikir tingkat tinggi. Sumber yang dimaksud berupa Peraturan Menteri Pendidikan dan Kebudayaan (Permendikbud) sebagai dasar dalam mengembangkan perangkat pembelajaran. Buku panduan pembelajaran HOTS sebagai dasar mengembangkan pembelajaran berorientasi pada keterampilan berpikir tingkat tinggi. Buku guru, buku siswa, dan beberapa buku matematika kelas VIII dari berbagai penerbit sebagai dasar penentuan dan penyusunan materi pembelajaran. Buku panduan penilaian sebagai dasar penyusunan instrumen penilaian hasil belajar siswa. Langkah selanjutnya peneliti membuat rancangan awal silabus, RPP dan LKS yang akan dikembangkan. Silabus dan RPP yang dikembangkan sesuai dengan Permendikbud No. 22 Tahun 2016 dengan model Problem Based Learning dan pada kegiatan pembelajaran melibatkan proses kognitif sesuai dengan level kognitif Bloom yang memenuhi kriteria C3 (menganalisis), C4(mengevaluasi), dan C5(mencipta). LKS yang dikembangkan sesuai dengan karakteristik model Problem Based Learning dan isi LKS didominasi oleh pertanyaan yang dapat memancing kemampuan berpikir siswa.

Pada tahap development, perangkat pembelajaran dikembangkan sesuai dengan rancangan yang telah ditentukan pada tahap design. Setelah melengkapi komponen silabus dan RPP, peneliti menuliskan Kompetensi Inti (KI) sebagai tahap pertama mengembangkan silabus pembelajaran matematika berorientasi berpikir tingkat tinggi. Kompetensi Inti (KI) yang dituliskankan mengacu pada Permendikbud Nomor 21 tahun 2016.

Setelah menuliskan kompetensi inti yang sesuai, peneliti menuliskan Kompetensi Dasar (KD) materi pokok peluang yang mengacu pada Permendikbud Nomor 24 tahun 2016. Setelah menuliskankan KD, peneliti menentukan target pengetahuan dan keterampilan yang akan dicapai siswa sesuai dengan KD yang dipilih. Dalam merealisasikan pembelajaran berorientasi berpikir tingkat tinggi, peneliti mengkombinasikan dimensi pengetahuan dengan proses berpikir yang harus dialami siswa. Kombinasi tersebut peneliti proyeksikan dalam sumbu simetri seperti pada Tabel 1.

Tabel 1.

Kombinasi dimensi pengetahuan dengan proses berpikir dalam materi peluang

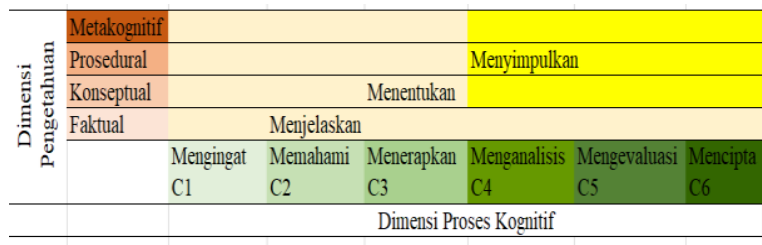

Kombinasi dimensi pengetahuan ditetapkan untuk satu kompetensi dasar yang menunjukkan adanya proses berpikir hingga pada proses berpikir yang terkategori higher oreder thinking skills. Setelah menentukan kombinasi dimensi pengetahuan dan proses berpikir yang harus dialami siswa, selanjutnya peneliti menentukan Indikator Pencapaian Kompetensi (IPK) yang dirumuskan berdasarkan kompetensi dasar pada materi peluang dengan gradasi IPK diidentifikasi dari Lower Order Thinking Skill menuju Higher Order Thinking Skill.

Selain KD dan IPK, terdapat kolom kegiatan pembelajaran. Kegiatan pembelajaran dibuat berdasarkan pada langkah-langkah pembelajaran pada model Problem Based Learning dan pendekatan saintifik. Peneliti melibatkan keterampilan berpikir tingkat tinggi siswa pada kegiatan menalar dalam fase membimbing penyelidikan individu maupun kelompok. Selain kegiatan pembelajaran, pada kolom penilaian, peneliti menggunakan tes tertulis dalam bentuk uraian untuk penilaian 
keterampilan. Tes yang dibuat berisi masalah yang melibatkan keterampilan berpikir tingkat tinggi siswa.

Pada bagian isi, LKS dibuat berdasarkan model Problem Based Learning. LKS menampilkan Kegiatan Siswa yang merupakan kegiatan-kegiatan yang akan dilakukan siswa untuk mencapai tujuan pembelajaran. LKS diawali dengan menyajikan masalah kontekstual yang sesuai dengan materi pembelajaran. Salah satu contoh masalah kontekstual yang terdapat pada LKS disajikan pada Gambar 2.

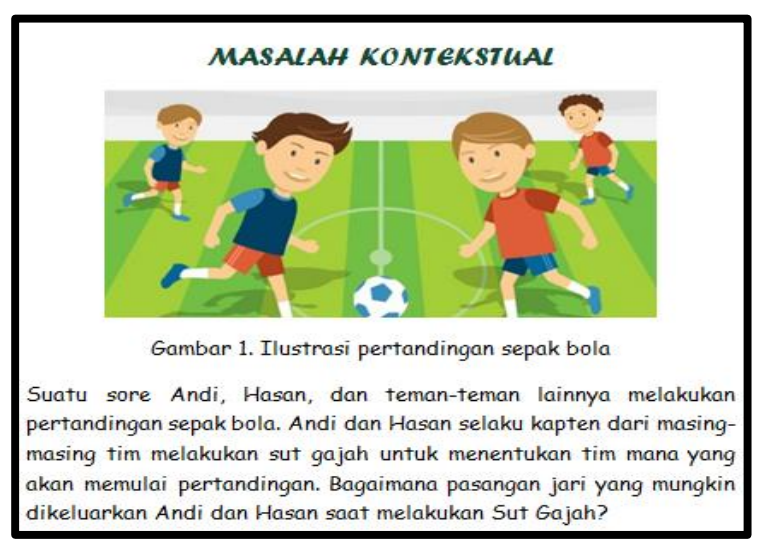

Gambar 2. Masalah kontekstual yang disajikan dalam salah satu LKS yang dikembangkan

LKS dilanjutkan dengan Kegiatan Siswa yang merupakan kegiatan yang harus diselesaikan siswa untuk mencapai tujuan pembelajaran dalam satu kali pertemuan. Kegiatan siswa didominasi oleh pertanyaan sehingga siswa diajak untuk berpikir dan dapat mengembangkan keterampilan berpikir tingkat tingginya. Gambar 3, gambar 4, dan gambar 5 menampilkan kegiatan siswa yang terdapat dalam salah satu LKS yang dikembangkan.

Kegiatan Siswa - 1

Lakukan reka adegan saat Andi dan Hasan melakukan sut gajah bersama dengan salah satu teman sekelompokmu untuk menemukan jawaban dari pertanyaan yang diberikan. Lakukan kegiatan berulang dengan mengeluarkan jari yang berbeda untuk mengumpulkan informasi yang dibutuhkan. Kemudian catat pasangan jari yang muncul. Misalkan

Telunjuk $x$ Telunjuk

Ibu Jari $\times$ Telunjuk

Gambar 3. Kegiatan siswa yang terdapat dalam salah satu LKS yang dikembangkan

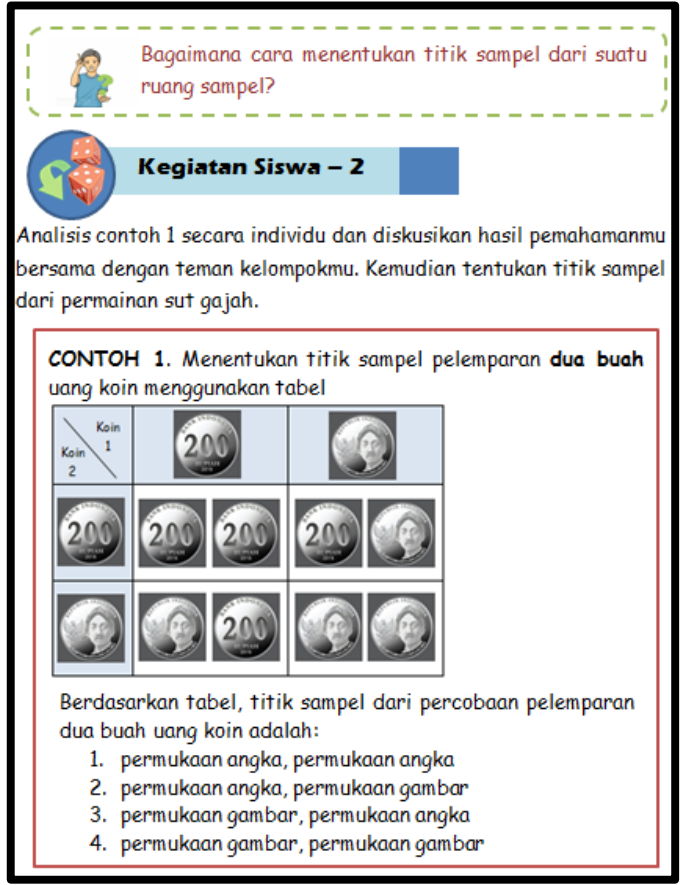

Gambar 4. Kegiatan siswa yang terdapat dalam salah satu LKS yang dikembangkan

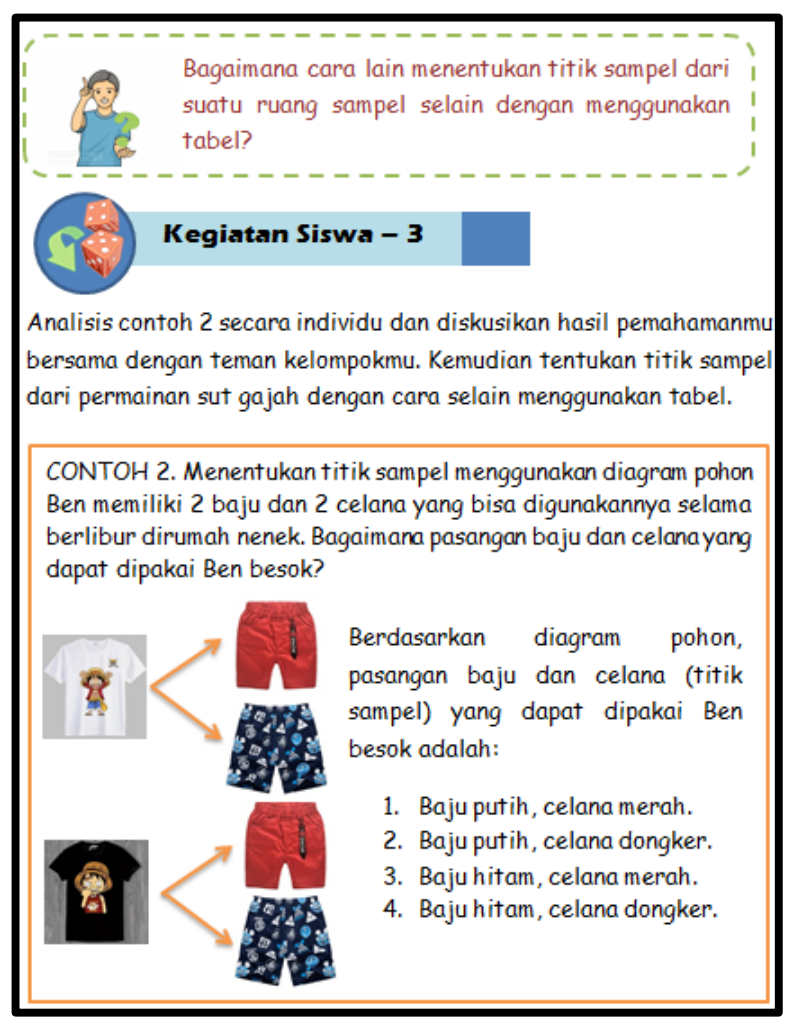

Gambar 5. Kegiatan siswa yang terdapat dalam salah satu LKS yang dikembangkan

Setiap bagian akhir LKS diberikan beberapa soal latihan yang berkaitan dengan 
materi yang dipelajari bertujuan untuk melatih siswa agar lebih memahami konsep pelajaran dengan baik. Gambar 6 menunjukkan soal latihan yang terdapat dalam salah satu LKS yang dikembangkan.

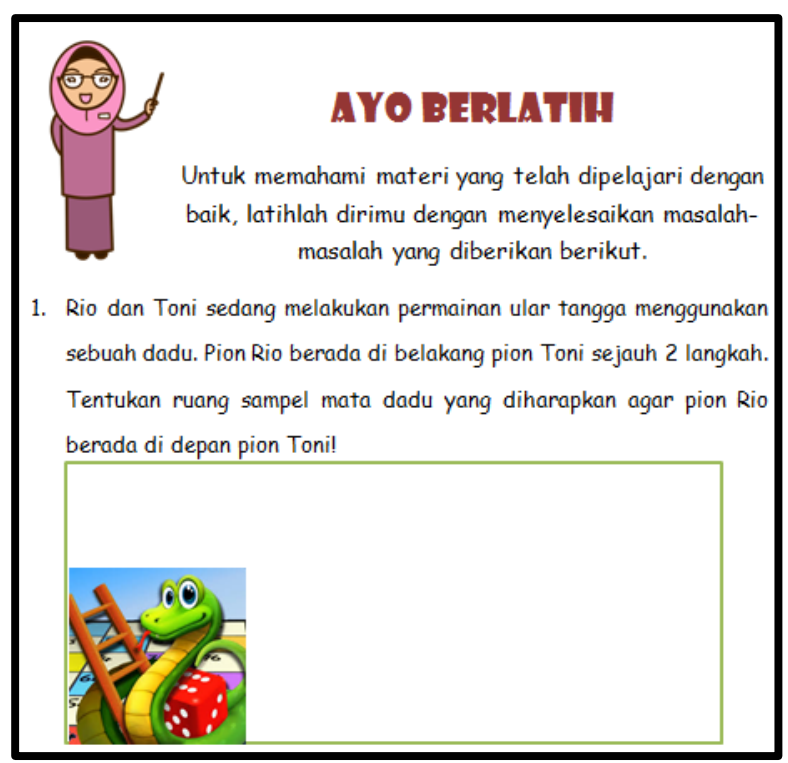

Gambar 6. Soal latihan yang terdapat dalam salah satu LKS yang dikembangkan

Setelah perangkat pembelajaran selesai dikembangkan, selanjutnya adalah tahap implementation, pada tahap ini silabus, RPP, dan LKS yang telah dikembangkan kemudian divalidasi oleh dua orang dosen Pendidikan Matematika dan seorang guru matematika SMP. Sejalan dengan itu, dilakukan evaluasi satu-satu terhadap LKS yang telah dikembangkan. Kegiatan ini bertujuan untuk mengevaluasi keterbacaan LKS dan menemukan kesulitan siswa dalam mengerjakan LKS. Silabus, RPP dan LKS kemudian direvisi sesuai saran validator dan hasil kerja siswa saat evaluasi satu-satu.

\section{Pembahasan Nilai Validasi Silabus}

Indikator penilaian untuk aspek penilaian silabus disajikan melalui kisi-kisi pada tabel 2. Setelah dilakukan tahap validasi didapatkan hasil penilaian silabus seperti Tabel 3. Secara keseluruhan silabus pembelajaran matematika berorientasi berpikir tingkat tinggi pada materi peluang kelas VIII SMP dikategorikan valid. Identitas silabus sudah sesuai dengan Permendikbud No. 22 Tahun 2016, serta kompetensi inti dan kompetensi dasar ditulis dengan lengkap dan benar.

Tabel 2 .

Indikator penilaian untuk aspek penilaian silabus

\begin{tabular}{ll}
\hline Aspek yang Dinilai & \multicolumn{1}{c}{ Indikator Penilaian } \\
\hline \multirow{2}{*}{ Kelengkapan } & Identitas Silabus \\
Komponen Silabus & Kompetensi Inti \\
& Kompetensi Dasar \\
\hline \multirow{2}{*}{ Rumusan IPK } & Kesesuaian dengan Kompetensi Dasar \\
& Kesesuaian Kata Kerja Operasional dengan Kompetensi \\
& Dasar \\
\hline Pemilihan Materi & Kesesuaian dengan KD dan IPK \\
Pembelajaran & Ketepatan Susunan Materi Pembelajaran \\
\hline Langkah-langkah & Kegiatan Pembelajaran Berorientasi pada Keterampilan \\
Pembelajaran & Berpikir Tingkat Tinggi \\
\hline Penilaian hasil & Mencakup Aspek Pengetahuan dan Keterampilan \\
belajar siswa & Kesesuaian dengan Indikator Pencapaian Kompetensi \\
\hline
\end{tabular}

Tabel 3.

Hasil penilaian silabus

\begin{tabular}{|c|c|c|c|c|c|c|}
\hline \multirow{2}{*}{ No } & \multirow{2}{*}{ Aspek yang dinilai } & \multicolumn{3}{|c|}{ Nilai validator } & \multirow{2}{*}{$\begin{array}{c}\text { Validasi } \\
\text { Gabungan }\end{array}$} & \multirow{2}{*}{$\begin{array}{c}\text { Kategori } \\
\text { Validasi }\end{array}$} \\
\hline & & 1 & 2 & 3 & & \\
\hline 1 & Identitas Silabus & $100 \%$ & $100 \%$ & $100 \%$ & $100 \%$ & Sangat Valid \\
\hline 2 & Kompetensi Inti & $100 \%$ & $100 \%$ & $100 \%$ & $100 \%$ & Sangat Valid \\
\hline 3 & Kompetensi Dasar & $100 \%$ & $100 \%$ & $100 \%$ & $100 \%$ & Sangat Valid \\
\hline 4 & $\begin{array}{l}\text { Kesesuaian IPK } \\
\text { dengan } \mathrm{KD}\end{array}$ & $100 \%$ & $100 \%$ & $80 \%$ & $93 \%$ & Sangat Valid \\
\hline 5 & $\begin{array}{l}\text { Kesesuaian Kata Kerja } \\
\text { Operasional dengan } \\
\text { KD }\end{array}$ & $60 \%$ & $100 \%$ & $80 \%$ & $80 \%$ & Valid \\
\hline 6 & $\begin{array}{l}\text { Kesesuaian Materi } \\
\text { Pembelajaran dengan } \\
\text { KD dan IPK }\end{array}$ & $80 \%$ & $100 \%$ & $100 \%$ & $93 \%$ & Sangat Valid \\
\hline 7 & $\begin{array}{l}\text { Susunan Materi } \\
\text { Pembelajaran }\end{array}$ & $80 \%$ & $100 \%$ & $100 \%$ & $93 \%$ & Sangat Valid \\
\hline 8 & $\begin{array}{l}\text { Langkah Pembelajaran } \\
\text { Berorientasi } \\
\text { Kemampuan Berpikir } \\
\text { Tingkat Tinggi }\end{array}$ & $80 \%$ & $100 \%$ & $100 \%$ & $93 \%$ & Sangat Valid \\
\hline 9 & $\begin{array}{l}\text { Cakupan Aspek } \\
\text { Penilaian }\end{array}$ & $80 \%$ & $80 \%$ & $100 \%$ & $87 \%$ & Sangat Valid \\
\hline 10 & $\begin{array}{l}\text { Kesesuaian Penilaian } \\
\text { dengan IPK }\end{array}$ & $80 \%$ & $80 \%$ & $100 \%$ & $87 \%$ & Sangat Valid \\
\hline
\end{tabular}

Seluruh indikator pencapaian kompetensi pada silabus sesuai dengan kompetensi dasar pengetahuan dan keterampilan. Sedangkan kesesuaian kata kerja operasional dengan kompetensi dasar dapat dikategorikan valid namun harus dilakukan perbaikan. Peneliti melakukan perbaikan terhadap pemilihan kata kerja operasional yang sesuai dengan kompetensi dasar pengetahuan dan keterampilan. Pembagian materi pembelajaran dalam silabus sesuai dengan tuntutan kompetensi dasar dan terurut secara sistematis. Kegiatan pembelajaran yang dijelaskan dalam silabus merupakan kegiatan yang melibatkan keterampilan berpikir tingkat tinggi siswa. Penilaian silabus mencakup aspek pengetahuan dan keterampilan, serta sesuai dengan indikator pencapaian kompetensi. 


\section{Pembahasan Nilai Validasi RPP}

Indikator penilaian untuk aspek penilaian RPP disajikan melalui kisi-kisi pada tabel 4

Tabel 4.

Indikator penilaian untuk aspek penilaian RPP

\begin{tabular}{|c|c|}
\hline Aspek Penilaian & Indikator Penilaian \\
\hline Kelengkapan RPP & $\begin{array}{l}\text { Identitas RPP } \\
\text { Kompetensi Inti } \\
\text { Kompetensi Dasar }\end{array}$ \\
\hline $\begin{array}{l}\text { Rumusan } \\
\text { Indikator }\end{array}$ & $\begin{array}{l}\text { Kesesuaian dengan Kompetensi Dasar } \\
\text { Kesesuaian Kata Kerja Operasional dengan KD }\end{array}$ \\
\hline $\begin{array}{l}\text { Pencapaian } \\
\text { Kompetensi }\end{array}$ & Kesesuaian dengan Aspek Penilaian \\
\hline $\begin{array}{l}\text { Rumusan Tujuan } \\
\text { Pembelajaran }\end{array}$ & $\begin{array}{l}\text { Kesesuaian dengan Indikator Pencapaian Kompetensi } \\
\text { Ketepatan Pemilihan Kata Keria Operasional } \\
\text { Mencakup Aspek Pengetahuan dan Keterampilan } \\
\text { Mencakup Aspek Audience, Behavior, Condition, } \\
\text { dan Degree. }\end{array}$ \\
\hline $\begin{array}{l}\text { Deskripsi Materi } \\
\text { Pembelajaran }\end{array}$ & $\begin{array}{l}\text { Kesesuaian dengan KD dan IPK } \\
\text { Susunan Materi Pembelajaran } \\
\text { Ketepatan Fakta, Konsep, Prinsip, dan Prosedur }\end{array}$ \\
\hline $\begin{array}{l}\text { Pendekatan, } \\
\text { Model, Metode } \\
\text { Pembelajaran }\end{array}$ & $\begin{array}{l}\text { Kesesuaian dengan Kompetensi Dasar, Karakteristik } \\
\text { Materi, dan Karakteristik Siswa }\end{array}$ \\
\hline $\begin{array}{l}\text { Pemilihan Alat/ } \\
\text { Bahan dan Media } \\
\text { Pembelajaran }\end{array}$ & $\begin{array}{l}\text { Kesesuaian dengan Tujuan Pembelajaran dan Materi } \\
\text { Pembelajaran }\end{array}$ \\
\hline $\begin{array}{l}\text { Ketepatan } \\
\text { Kegiatan } \\
\text { Pembelajaran }\end{array}$ & $\begin{array}{l}\text { Kegiatan Pembelajaran berdasarkan Model PBL } \\
\text { Kegiatan Pembelajaran Berorientasi pada } \\
\text { Kemampuan Berpikir Tingkat Tinggi Siswa }\end{array}$ \\
\hline $\begin{array}{l}\text { Instrumen } \\
\text { Penilaian Hasil } \\
\text { Belajar }\end{array}$ & $\begin{array}{l}\text { Cakupan Aspek Penilaian } \\
\text { Kesesuaian dengan tujuan pembelajaran atau IPK } \\
\text { Komponen Penilaian } \\
\text { Mengasah Keterampilan Berpikir Tingkat Tinggi } \\
\text { Siswa }\end{array}$ \\
\hline $\begin{array}{l}\text { Kegiatan } \\
\text { Remedial dan } \\
\text { Pengayaan }\end{array}$ & Merencanakan Kegiatan Remedial dan Pengayaan \\
\hline
\end{tabular}

Setelah dilakukan tahap validasi didapatkan hasil penilaian RPP seperti tabel 5.

Tabel 5.

Hasil penilaian RPP

\begin{tabular}{|c|c|c|c|c|c|c|c|}
\hline \multirow[t]{2}{*}{ No } & \multirow{2}{*}{$\begin{array}{c}\text { Aspek yang } \\
\text { dinilai }\end{array}$} & \multicolumn{4}{|c|}{$\begin{array}{c}\text { Validasi Gabungan untuk } \\
\text { RPP- } \\
\end{array}$} & \multirow{2}{*}{$\begin{array}{l}\text { Validasi } \\
\text { Gabungan }\end{array}$} & \multirow{2}{*}{$\begin{array}{l}\text { Kategori } \\
\text { Validasi }\end{array}$} \\
\hline & & & 2 & 3 & 4 & & \\
\hline 1 & Identitas RPP & $100 \%$ & $100 \%$ & $100 \%$ & $100 \%$ & $100 \%$ & $\begin{array}{l}\text { Sangat } \\
\text { Valid }\end{array}$ \\
\hline 2 & Kompetensi Inti & $100 \%$ & $100 \%$ & $100 \%$ & $100 \%$ & $100 \%$ & $\begin{array}{l}\text { Sangat } \\
\text { Valid }\end{array}$ \\
\hline 3 & $\begin{array}{l}\text { Kompetensi } \\
\text { Dasar }\end{array}$ & $93 \%$ & $100 \%$ & $100 \%$ & $93 \%$ & $97 \%$ & $\begin{array}{c}\text { Sangat } \\
\text { Valid }\end{array}$ \\
\hline 4 & $\begin{array}{l}\text { Indikator } \\
\text { Pencapaian } \\
\text { Kompetensi }\end{array}$ & $82 \%$ & $87 \%$ & $84 \%$ & $82 \%$ & $84 \%$ & Valid \\
\hline 5 & $\begin{array}{l}\text { Tujuan } \\
\text { Pembelajaran }\end{array}$ & $88 \%$ & $90 \%$ & $87 \%$ & $85 \%$ & $88 \%$ & $\begin{array}{l}\text { Sangat } \\
\text { Valid }\end{array}$ \\
\hline 6 & $\begin{array}{l}\text { Materi } \\
\text { Pembelajaran }\end{array}$ & $100 \%$ & $98 \%$ & $91 \%$ & $93 \%$ & $96 \%$ & $\begin{array}{c}\text { Sangat } \\
\text { Valid }\end{array}$ \\
\hline 7 & $\begin{array}{l}\text { Pendekatan, } \\
\text { Model dan } \\
\text { Metode } \\
\text { Pembelajaran }\end{array}$ & $98 \%$ & $100 \%$ & $87 \%$ & $89 \%$ & $93 \%$ & $\begin{array}{l}\text { Sangat } \\
\text { Valid }\end{array}$ \\
\hline 8 & $\begin{array}{l}\text { Media, Alat, dan } \\
\text { Bahan } \\
\text { Pembelajaran }\end{array}$ & $93 \%$ & $87 \%$ & $84 \%$ & $84 \%$ & $87 \%$ & $\begin{array}{l}\text { Sangat } \\
\text { Valid }\end{array}$ \\
\hline 9 & $\begin{array}{l}\text { Langkah- } \\
\text { langkah } \\
\text { Pembelajaran }\end{array}$ & $96 \%$ & $89 \%$ & $89 \%$ & $86 \%$ & $90 \%$ & $\begin{array}{c}\text { Sangat } \\
\text { Valid }\end{array}$ \\
\hline 10 & Penilaian & $92 \%$ & $92 \%$ & $93 \%$ & $90 \%$ & $92 \%$ & $\begin{array}{l}\text { Sangat } \\
\text { Valid }\end{array}$ \\
\hline 11 & $\begin{array}{l}\text { Merencanakan } \\
\text { kegiatan } \\
\text { pengayaan dan } \\
\text { remedial }\end{array}$ & $87 \%$ & $87 \%$ & $87 \%$ & $80 \%$ & $85 \%$ & Valid \\
\hline
\end{tabular}

Secara keseluruhan RPP pembelajaran matematika berorientasi berpikir tingkat tinggi pada materi peluang kelas VIII SMP dikategorikan valid. Identitas RPP sudah sesuai dengan Permendikbud No. 22 tahun 2016 serta kompetensi inti dan kompetensi dasar ditulis dengan lengkap dan benar. Kompetensi dasar dapat dijabarkan dalam indikator pencapaian kompetensi. Sedangkan indikator pencapaian kompetensi pada RPP-4 dikategorikan valid namun harus dilakukan perbaikan, peneliti melakukan perbaikan dalam penetapatan indikator pencapaian kompetensi yang sesuai dengan kompetensi dasar pengetahuan dan keterampilan. Indikator pencapaian kompetensi yang ditetapkan dapat dioperasionalkan. Sedangkan kata kerja operasional pada RPP-4 dikategorikan valid namun harus dilakukan perbaikan, peneliti melakukan perbaikan dalam pemilihan kata kerja operasional yang sesuai dengan kompetensi dasar pengetahuan dan keterampilan. Kemudian indikator pencapaian kompetensi yang ditetapkan sesuai dengan aspek penilaian pengetahuan dan keterampilan.

Rumusan tujuan pembelajaran masingmasing RPP sesuai dengan indikator pencapaian kompetensi. Pemilihan kata kerja operasional untuk masing-masing RPP dikategorikan valid, artinya RPP-1, RPP-2, dan RPP-3 menggunakan kata kerja yang dapat diamati dan diukur. Sedangkan kata kerja operasional untuk RPP-4 dikategorikan valid namun harus dilakukan perbaikan, peneliti melakukan perbaikan dalam pemilihan kata kerja operasional yang dapat diukur dan diamati. Tujuan pembelajaran pada RPP mencakup aspek pengetahuan dan keterampilan. Selanjutnya tujuan pembelajaran pada RPP mencakup aspek audience, behavior, condition, dan degree.

Materi pembelajaran yang disajikan dalam RPP sesuai dengan kompetensi dasar dan indikator pencapaian kompetensi yang telah ditetapkan. Nilai yang sama untuk materi pembelajaran ditulis secara terurut dan lengkap, serta memuat fakta, konsep, prinsip, dan prosedur yang relevan. Pendekatan, model, dan metode pembalajaran setiap RPP telah sesuai dengan 


\section{JURNAL GANTANG. Maret 2021; VI(1): 61 - 73 \\ p-ISSN. 2503-0671 \\ e-ISSN. 2548-5547}

kompetensi dasar, karakteristik materi pembelajaran, dan karakteristik siswa. Media dan alat pembelajaran telah sesuai dengan tujuan pembelajaran, materi pembelajaran, dan kondisi kelas. Namun untuk bahan pembelajaran di masing-masing RPP dapat dikategorikan valid dengan adanya perubahan, salah satu validator memberi saran untuk merincikan bahan-bahan yang dibutuhkan dalam kegiatan pembelajaran.

Secara keseluruhan tahapan kegiatan pembelajaran dalam masing-masing RPP dinilai valid yaitu tahapan pembelajaran mencakup tahapan pendahuluan, inti, dan penutup dan disertai alokasi waktu di setiap tahapan. Selain itu, kegiatan pendahuluan ditulis secara lengkan dan benar; menyiapkan siswa secara psikis dan fisik, memberi motivasi belajar, melakukan apersepsi, menjelaskan tujuan pembelajaran atau kompetensi dasar, serta seluruh kegiatan penutup ditulis secara lengkap dan benar; membuat simpulan, tindak lanjut, dan menginformasikan rencana kegiatan pembelajaran untuk pertemuan berikutnya.

RPP memberikan masalah yang akan dipecahkan siswa secara berkelompok; memberi ruang siswa untuk berdiskusi dan membagi tugas untuk mencari data yang diperlukan untuk menyelesaikan masalah; membimbing siswa melakukan penyelidikan (mencari data) untuk bahan diskusi kelompok; melatih siswa melakukan diskusi kelompok untuk menghasilkan solusi pemecahan masalah dan penyajian hasil diskusi kelompok; serta meminta siswa untuk merangkum/membuat kesimpulan sesuai dengan masukan yang diperoleh saat melakukan presentasi.

Secara garis besar, pembelajaran berorientasi keterampilan berpikir tingkat tinggi pada masing-masing RPP dikategorikan valid. Validator menyatakan sesuai untuk pernyataan yang menyatakan bahwa secara keseluruhan kegiatan pembelajaran merupakan kegiatan yang melibatkan berpikir tingkat tinggi siswa. Kegiatan pembelajaran berpikir tingkat tinggi diupayakan melalui melibatkan proses kognitif siswa berdasarkan level kognitif Bloom. Kegiatan pada masing-masing RPP dinilai valid melibatkan proses kognitif menerapkan, menganalisis, mengevaluasi, dan mencipta.

Penilaian siswa mencakup aspek pengetahuan dan keterampilan. Selain itu, penilaian pada setiap akhir RPP telah sesuai dengan tujuan pembelajaran atau indikator pencapaian kompetensi yang telah ditetapkan.

Secara teknis komponen penilaian masing-masing RPP dinyatakan valid, yang mana penilaian siswa meliputi kisi-kisi, soal, kunci jawaban penilaian pengetahuan dan kisi-kisi, soal, rubrik penilaian keterampilan secara lengkap dan benar. Secara kualitas penilaian dinilai valid untuk melatih keterampilan berpikir tingkat tinggi siswa. Serta setiap RPP merencanakan kegiatan pengayaan bagi siswa yang memiliki kemampuan lebih dan kegiatan remedial bagi siswa yang memiliki kemampuan kurang dengan baik.

\section{Pembahasan Nilai Validasi LKS}

Indikator penilaian untuk aspek penilaian LKS disajikan melalui kisi-kisi pada tabel 6 .

Tabel 6.

Indikator penilaian untuk aspek penilaian LKS

\begin{tabular}{ll}
\hline Aspek Penilaian & \multicolumn{1}{c}{ Indikator Penilaian } \\
\hline Materi Pelajaran & $\begin{array}{l}\text { Kesesuaian dengan Tujuan Pembelajaran } \\
\text { Kesistematisan Urutan Materi }\end{array}$ \\
\hline Langkah Kerja & Orientasi Siswa pada Masalah \\
Problem Based & Mengorganisasikan Siswa untuk Belajar \\
Learning & Membimbing Penyelidikan Individu Maupun Kelompok \\
\hline Pembelajaran & Mengembangkan dan Menyajikan Hasil Karya \\
Berorientasi & Keterlibatan Proses Kognitif Menganalisis \\
Berpikir Tingkat & Keterlibatan Proses Kognitif Menilai/ Mengevaluasi \\
Tinggi & Keterlibatan Siswa Kognitif Mengkreasi/ Mencipta \\
\hline Pemilihan & Masalah Sesuai dengan Lingkungan dian Kehidupan Siswa \\
Masalah & Kemenarikan Masalah yang Disajikan \\
Matematika & Pemilihan Soal Latihan Sesuai dengan Materi yang \\
\hline & Disajikan \\
\hline & Penggunaan Bahasa Sesuai Tingkat Kognitif Siswa \\
Penyajian LKS & Penyajian Ilustrasi Gambar \\
& Kejelasan Tulisan \\
& Kemenarikan Tampilan LKS
\end{tabular}

Setelah dilakukan tahap validasi didapatkan hasil penilaian LKS seperti tabel 7. Secara keseluruhan LKS pembelajaran matematika berorientasi berpikir tingkat tinggi pada materi peluang kelas VIII SMP dikategorikan valid.

LKS yang dikembangkan menyajikan materi yang sesuai dengan tujuan pembelajaran 
serta materi yang disajikan terurut secara sistematis. LKS yang dikembangkan memberikan masalah yang akan dipecahkan siswa secara berkelompok pada pembukaan LKS. Selanjutnya LKS yang dikembangkan memberi ruang kepada siswa untuk berdiskusi dan membagi tugas untuk mencari data yang diperlukan untuk menyelesaikan masalah. Selain itu LKS yang dikembangkan menggiring siswa untuk melakukan penyelidikan (mencari data) untuk bahan diskusi kelompok. Terakhir, LKS yang dikembangkan memfasilitasi siswa melakukan diskusi kelompok untuk menghasilkan solusi pemecahan masalah dan penyajian hasil diskusi kelompok.

Tabel 7.

Hasil penilaian LKS

\begin{tabular}{|c|c|c|c|c|c|c|c|}
\hline \multirow[t]{2}{*}{ No } & \multirow{2}{*}{$\begin{array}{l}\text { Aspek yang } \\
\text { dinilai }\end{array}$} & \multicolumn{4}{|c|}{$\begin{array}{c}\text { Validasi Gabungan untuk } \\
\text { LKS- }\end{array}$} & \multirow{2}{*}{$\begin{array}{c}\text { Validasi } \\
\text { Gabungan }\end{array}$} & \multirow{2}{*}{$\begin{array}{l}\text { Kategori } \\
\text { Validasi }\end{array}$} \\
\hline & & 1 & 2 & 3 & 4 & & \\
\hline 1 & $\begin{array}{l}\text { Materi } \\
\text { Pembelajaran }\end{array}$ & $93 \%$ & $93 \%$ & $97 \%$ & $100 \%$ & $96 \%$ & $\begin{array}{l}\text { Sangat } \\
\text { Valid }\end{array}$ \\
\hline 2 & $\begin{array}{l}\text { Langkah Kerja } \\
\text { Problem Based } \\
\text { Learning }\end{array}$ & $100 \%$ & $95 \%$ & $95 \%$ & $88 \%$ & $95 \%$ & $\begin{array}{c}\text { Sangat } \\
\text { Valid }\end{array}$ \\
\hline 3 & $\begin{array}{l}\text { Pembelajaran } \\
\text { Berorientasi } \\
\text { Berpikir } \\
\text { Tingkat Tinggi }\end{array}$ & $87 \%$ & $83 \%$ & $82 \%$ & $83 \%$ & $84 \%$ & Valid \\
\hline 4 & $\begin{array}{l}\text { Pemilihan } \\
\text { Masalah } \\
\text { Matematika }\end{array}$ & $87 \%$ & $87 \%$ & $87 \%$ & $84 \%$ & $86 \%$ & $\begin{array}{c}\text { Sangat } \\
\text { Valid }\end{array}$ \\
\hline 5 & Penyajian LKS & $87 \%$ & $95 \%$ & $90 \%$ & $92 \%$ & $91 \%$ & $\begin{array}{l}\text { Sangat } \\
\text { Valid } \\
\end{array}$ \\
\hline
\end{tabular}

Kegiatan dalam LKS dinilai valid melibatkan siswa pada proses kognitif mengaplikasi, berarti LKS yang dikembangkan dinilai melibatkan kegiatan melakukan atau menggunakan prosedur atau konsep dalam suatu situasi. Kemudian kegiatan dalam LKS juga dinilai valid melibatkan siswa pada proses kognitif menganalisis, yang artinya LKS yang dikembangkan melibatkan kegiatan pemecahan materi dan penentuan bagaimana hubungan antarbagian.

Selanjutnya LKS yang dikembangkan melibatkan siswa pada proses kognitif mengevaluasi, maksudnya LKS yang dikembangkan melibatkan kegiatan membuat pertimbangan berdasarkan kriteria atau suatu standar. Terakhir kegiatan dalam LKS yang dikembangkan melibatkan siswa pada proses kognitif mencipta, yaitu LKS yang dikembangkan melibatkan kegiatan menyusun kembali unsurunsur ke dalam pola atau struktur baru. Secara keseluruhan LKS dinilai valid melibatkan kemampuan berpikir siswa.

Masalah kontekstual disajikan pada setiap LKS sesuai dengan lingkungan dan dekat dengan kehidupan siswa serta dapat memancing rasa ingin tahu siswa. Selain itu masalah pada latihan soal setiap akhir sub kegiatan sesuai dengan materi yang disajikan.

Secara keseluruhan penyajian setiap LKS dikategorikan valid untuk: penggunaan bahasa dalam LKS dinilai sederhana, jelas dan sesuai dengan tingkat kemampuan kognitif siswa SMP; ilustrasi gambar yang disajikan sesuai dengan masalah atau materi pembelajaran; huruf dan angka dalam LKS dapat dibaca dan jelas; serta tampilan cover dan isi LKS menarik.

Hasil penelitian terhadap tingkat validitas LKS yang dikembangkan sejalan dengan hasil penelitian oleh Khairunisa, dkk (2020), yaitu penelitian yang hanya melibatkan tiga tahapan penelitian ADDIE menghasilkan lembar kerja siswa degan model Problem Based Learning berbasis Higher Order Thinking Skill yang dinilai valid dan layak untuk digunakan. LKS yang valid disebabkan oleh beberapa faktor, yaitu: komponen-komponen LKS dengan model Problem Based Learning berbasis Higher Order Thinking Skills yang dikembangkan sesuai dengan indikator yang telah ditetapkan pada instrumen validasi dan didasari pada teori-teori pengembangan.

Beberapa penelitian terdahulu memperoleh hasil yang serupa mengenai pembelajaran berorientasi berpikir tingkat tinggi dengan model problem based learning. Pemanfaatan perangkat pembelajaran model problem based learning efektif untuk meningkatkan HOTS dan lebih baik dibandingkan dengan pembelajaran langsung untuk meningkatkan HOTS. Ada beberapa faktor yang menyebabkan pemanfaatan perangkat pembelajaran berbasis masalah efektif untuk 


\section{JURNAL GANTANG. Maret 2021; VI(1): 61 - 73 \\ p-ISSN. 2503-0671 \\ e-ISSN. 2548-5547}

meningkatkan HOTS dan karakter siswa diantaranya: (1) pengajuan masalah yang menantang dalam PBL meningkatkan motivasi siswa untuk belajar; (2) tahapan dalam PBL menjadikan siswa lebih aktif dalam kegiatan pembelajaran; (3) pengajuan masalah kontekstual dalam Lembar Kerja menjadikan siswa antusias untuk menyelesaikannya; (4) penerapan PBL dalam pembelajaran memotivasi siswa untuk mencari informasi melalui berbagai sumber; dan (5) adanya kelompok belajar dalam PBL menjadikan interaksi siswa dalam pembelajaran lebih dinamis (Jailani \& Retnawati, 2016).

Bila ditinjau dari respon siswa, hasil penelitian oleh Imelda \& Anzelina (2019) menjelaskan bahwa respon siswa terhadap pembelajaran PBL dalam meningkatkan HOTS siswa adalah respon positif. Hal ini diukur berdasarkan empat aspek yang tertuang dalam angket respon siswa yang digunakan yaitu aspek senang atau tidak senang, baru atau tidak baru, berminat atau tidak berminat, dan tertarik atau tidak tertarik. Siswa senang terhadap komponen pembelajaran, kebaruan komponen pembelajaran yang digunakan, siswa berminat mengikuti kegiatan pembelajaran PBL, dan tertarik pada bahasa, penampilan tulisan, ilustrasi guru dan letak gambar yang terdapat pada LKS.

Sedangkan bila ditinjau hasil belajar siswa, penelitian oleh Simatupang, dkk (2019) mendapatkan hasil tes perhitungan keterampilan higher order thinking siswa yang diajarkan dengan menggunakan problem based learning, dapat terlihat peningkatan antara nilai rata-rata pretest dengan nilai rata-rata posttest yaitu 10,27 dan 11,19 . Hal ini terlihat bahwa nilai rata-rata pretest lebih kecil dikarenakan belum diberikan materi dibandingkan dengan nilai rata-rata posttest yang tinggi karena sudah mendapatkan materi menggunakan problem based learning.

\section{Kesimpulan}

Penelitian pengembangan yang dilakukan menghasilkan produk berupa perangkat pembelajaran matematika berorientasi berpikir tingkat tinggi yang terdiri silabus, RPP, dan LKS melalui desain pengembangan ADDIE berdasarkan model Problem Based Learning pada materi peluang kelas VIII SMP/MTs. Perangkat pembelajaran yang dihasilkan disusun untuk empat kali pertemuan tatap muka pada materi peluang. Berdasarkan hasil penelitian dan pembahasan ditarik kesimpulan bahwa perangkat pembelajaran matematika berorientasi berpikir tingkat tinggi yang dikembangkan berdasarkan desain pengembangan dengan model Problem Based Learning pada materi peluang kelas VIII SMP/MTs telah memenuhi kriteria kesahan (valid).

\section{Referensi}

Ariyana, Y., Pudjiastuti, A., Bestary, R., \& Zamromi. (2018). Buku pegangan pembelajaran berorientasi pada keterampilan berpikir tingkat tinggi: program peningkatan kompetensi pembelajaran berbasis zonasi. Direktorat Jendral Guru Dan Tenaga Kependidikan.

Fatchiyah, F. (2016). Pengaruh PBL terhadap kemampuan berpikir tingkat tinggi siswa kelas V SD Se-Gugus 01 Kretek. Basic Education, 5(18), 1-746.

Fitriana, I. N., \& Mampouw, H, L. (2019). Skema kognitif siswa dalam menyelesaikan soal peluang ditinjau dari pendekatan Polya. Mosharafa: Jurnal Pendidikan Matematika, 8(3), 353-364.

Haryani, D. (2011). Pembelajaran matematika dengan pemecahan masalah untuk menumbuhkembangkan kemampuan berpikir kritis siswa. Prosiding Seminar Nasional Penelitian, Pendidikan Dan Penerapan MIPA, Fakultas MIPA, Universitas Negeri Yogyakarta, 1980.

Hasyim, M., \& Andreina, F. K. (2019). Analisis high order thinking skill (HOTS) siswa dalam menyelesaikan soal open ended matematika. FIBONACCI: Jurnal Pendidikan Matematika Dan Matematika, 5(1). https://doi.org/10.24853/fbc.5.1.55-64

Herman, T. (2007). Pembelajaran berbasis masalah untuk meningkatkan kemampuan berpikir matematis tingkat tinggi siswa sekolah menengah pertama. Educationist, l(1).

Imelda, I., \& Anzelina, D. (2019). Respon siswa terhadap pembelajaran problem based 
learning dalam meningkatkan higher order thinking skills. Mes: Journal of Mathematics Education and Science, 5(1), 11-19.

Jailani, \& Retnawati, H. (2016). Keefektifan pemanfaatan perangkat pembelajaran berbasis masalah untuk meningkatkan hots dan karakter siswa. Jurnal Pendidikan Dan Pembelajaran, 23(2).

Kasturi, K., Dafik, D., \& Darojat, O. (2015). Pengembangan perangkat pembelajaran problem posing berorientasi penerapan hots pada materi kesebangunan kelas IX. Pancaran Pendidikan, 4(1), 11-32.

Khairunisa, U., Azis, Z., \& Sembiring, M. B. (2020). Pengembangan lembar kerja peserta didik dengan model problem based learning berbasis higher order thinking skills. Mes: Journal of Mathematics Education and Science, 6(1), 56-61.

Kurniati, D., Harimukti, R., \& Jamil, N. A. (2016). Kemampuan berpikir tingkat tinggi siswa SMP di Kabupaten Jember dalam menyelesaikan soal berstandar PISA. Jurnal Penelitian Dan Evaluasi Pendidikan, 20(2). https://doi.org/10.21831/pep.v20i2.8058

Ngalimun, (2014). Strategi dan model pembelajaran. Yogyakarta: Aswaja Presindo.

Prasetyani, E., Hartono, Y., \& Susanti, E. (2016). Kemampuan berpikir tingkat tinggi siswa kelas xi dalam pembelajaran trigonometri berbasis masalah di SMA Negeri 18 Palembang. Jurnal Gantang, 1(1). https://doi.org/10.31629/jg.v1i1.4

Rayanto, Y, H,. \& Sugianti,. (2020). Penelitian pengembangan model ADDIE dan R2D2: Teori \& praktek. Pasuruan : Lembaga Academic \& Research Institute

Riadi, A. (2016). Problem-based learning meningkatkan higher-order thinking skills siswa kelas VIII SMPN 1 Daha Utara dan SMPN 2 Daha Utara. Math Didactic: Jurnal Pendidikan Matematika, 2(3). https://doi.org/10.33654/math.v2i3.44

Rusdi. (2018). Penelitian Desain dan Pengembangan Kependidikan (Konsep, Prosedur dan Sintesis Pengetahuan Baru). Depok: PT Raja Grafindo Persada.

Rusman. (2014). Model-model Pembelajaran: Mengembangankan Profesionalisme Guru.
Jakarta : Rajawali Pers.

Setiawan, T., \& Junaedi, I. (2012). Pengembangan perangkat pembelajaran matematika dengan pendekatan problem based learning untuk meningkatkan keterampilan higher order thinking. Unnes Journal of Mathematics Education Research, 1(1).

Sidek, M, N., \& Jamaludin, A. (2008). Pembinaan modul: Bagaimana membina modul latihan dan modul akademik. Serdang: Penerbit Universiti Putra Malaysia.

Simatupang, I. N., Hasibuan, L. R., \& Irmayanti, I. (2019). Pengembangan perangkat pembelajaran matematika dengan pendekatan problem based learning untuk meningkatkan keterampilan higher order thinking. Jurnal Pembelajaran Dan Matematika Sigma (JPMS), 5(2). https://doi.org/10.36987/jpms.v5i2.1561

Sugiyono. (2008). Metode Penelitian Kuantitatif, Kualitatif, dan $R \& D$. Alfabeta: Bandung.

Suhady, W., Roza, Y., \& Maimunah, M. (2020). Pengembangan soal untuk mengukur higher order thinking skill (hots) siswa. Jurnal Gantang, $5(2)$. https://doi.org/10.31629/jg.v5i2.2518

Susanto, E., \& Retnawati, H. (2016). Perangkat pembelajaran matematika bercirikan PBL untuk mengembangkan HOTS siswa SMA. Jurnal Riset Pendidikan Matematika, 3(2). https://doi.org/10.21831/jrpm.v3i2.10631

Trianto. 2014. Mendesain model pembelajaran inovatif, progresif, dan kontekstual: konsep, landasan, dan implementasinya pada Kurikulum 2013. Prenadamedia Group. Jakarta

Zaenal, A. (2010). Evaluasi pembelajaran. Bandung: PT. Remaja Rosdakarya 
JURNAL GANTANG. Maret 2021; VI(1): 61 - 73

p-ISSN. 2503-0671

e-ISSN. 2548-5547 